\title{
Brain Changes in Magnetic Resonance Imaging Caused by Child Abuse: A Systematic Literature Review.
}

\author{
Andrés Felipe Herrera Ortiz ${ }^{*}$, Nury Tatiana Rincón Cuenca $^{2}$, Lorena Josefina Fernández Beaujon ${ }^{1}$. \\ ${ }^{1}$ Médico Cirujano, Universidad el Bosque. Bogotá-Colombia. \\ ${ }^{2}$ Médico, Fundación Universitaria de Ciencias de la Salud (FUCS). Bogotá-Colombia.
}

\begin{abstract}
Introduction: Child maltreatment is a worldwide problem; not only for its repercussions at the time of the act but also for its possible sequelae, therefore, it is important to know and characterize the changes found in magnetic resonance, to correlate the structural outcome with its functional repercussions. This article seeks to unify and summarize what is already known.

Objective: To demonstrate brain changes and their functional repercussions using magnetic resonance imaging in people exposed to chronic child abuse.

Materials and methods: We performed a systematic literature review; the search was carried out through PubMed, LILACS, ScienceDirect, and Embase. The inclusion criteria were studies published in English, Spanish and French, between January 2015 and March 2020 that discussed the clinical and encephalic alterations in MRI caused by child abuse.

Results: 7 studies with a total of 760 participants were included with a mean age ranging between $6-35$ years. In $42 \%$ of the articles, alterations were evidenced at the level of the amygdala and hippocampus, defined as volume reduction or decreased connectivity. On the other hand, $28 \%$ of the articles included mentioned alterations at the level of the frontal cortex.

Conclusions: Child maltreatment produces brain anatomical and functional changes, which may be reversible if early intervention is performed by separating these children from the focus of abuse. It is possible to conclude that structural changes in the brain vary depending on the sub-type of child abuse; nevertheless, it remains controversial which changes correspond to each sub-type of child abuse. There is not enough literature to classify the anatomical variations caused by child abuse according to gender. Literature must be expanded to have enough evidence to emit a concept.
\end{abstract}

Keywords: Child Abuse, child abuse sexual, magnetic resonance imaging, brain, deprivation

\section{RESUMEN}

\section{Cambios Encefálicos en Resonancia Magnética Causados por Maltrato Infantil: Una Revisión Sistemática de la Literatura.}

Introducción: El maltrato infantil es una problemática a nivel mundial, no solo por sus repercusiones al momento del acto sino también por sus posibles secuelas, es indispensable conocer y caracterizar los cambios encontrados en la resonancia magnética para correlacionar las consecuencias estructurales con las funcionales. En este artículo se busca unificar y actualizar lo que se sabe hasta el momento.

Objetivo: Evidenciar los cambios encefálicos mediante resonancia magnética y sus repercusiones clínicas en personas expuestas a maltrato infantil crónico.

Materiales y métodos: Se realizó una revisión sistemática de la literatura; la búsqueda se llevó a cabo a través de PubMed, LILACS, ScienceDirect y Embase, incluyendo estudios en inglés, español y francés, entre enero del 2015 y marzo del 2020, se incluyeron estudios que evaluaran las alteraciones encefálicas y las repercusiones clínicas secundarias a maltrato infantil documentado por resonancia magnética.

Resultados: Se incluyeron 7 estudios con un total de 760 participantes, con edad media oscilando entre 6-35 años. En $42 \%$ de los artículos se evidenciaban alteraciones a nivel de la amígdala e hipocampo, definidas como una reducción del volumen o disminución de la conectividad. Por otro lado, en $28 \%$ de los artículos incluidos se mencionan alteraciones a nivel de la corteza frontal.

Conclusiones: El maltrato infantil produce cambios anatómicos y funcionales en el cerebro, los cuales pueden ser reversibles si se realiza una intervención temprana separando a estos niños del foco de abuso. Es posible concluir que los cambios estructurales a nivel cerebral varían dependiendo del subtipo de maltrato infantil, sin embargo, permanece en controversia cuales cambios corresponden a cada subtipo de maltrato infantil. No hay evidencia suficiente para clasificar las variaciones anatómicas causadas por maltrato infantil de acuerdo con el género. La literatura debe expandirse para contar con suficiente evidencia para emitir un concepto.

Keywords: Maltrato a los niños, abuso sexual infantil, imagen por resonancia magnética, encéfalo, deprivación

*Autor de correspondencia: Herrera Ortiz Andrés Felipe afherreraor@gmail.com

Como citar: Herrera Ortiz, A., Rincón Cuenca, N., \& Fernández Beaujon, $L$. (2021). Cambios Encefálicos en Resonancia Magnética Causados por Maltrato Infantil: Una Revisión Sistemática de la Literatura. Revista Cuarzo, 27(1), 27-33.

Recibido: 8 de enero de 2021 Aceptado: 16 de abril de 2021 Publicado: 30 de junio de 2021

Doi: https://doi.org/10.26752/cuarzo.v27.n1.522

License creative Commons 


\section{INTRODUCTION}

Cinidid hild abuse involves different sub-types within which we find neglect, sexual, physical, and emotional abuse (1).

Other authors include deprivation as a form of abuse. which refers to stressful events during childhood such as separation from the family unit, severe financial problems, suffering from serious illnesses or death of a family member (2).

According to the Colombian Institute of Family Welfare (ICBF), 77,780 reports of child abuse were received by 2012, of which 46,288 cases corresponded to children in early childhood, representing 59\% of the total cases (3). According to the World Health Organization (WHO), a quarter of the adult population reports child abuse, where one for every 13 men and one for every five women report having suffered sexual abuse during childhood (4). Child abuse is a global problem, so it is essential to know the implications it has on neurological development, as well as its possible functional and structural consequences.

Exposure to abuse and early stress produces a cascade of neurobiological events that have the potential to cause structural, functional, and neurohormonal changes during the brain development process (5). Childhood stress resulting from abuse generates serological elevation of catecholamines, corticotropin-releasing hormones, cortisol, and serotonin, which leads to apoptosis, abnormal neuronal pruning, delays in myelination, inhibition of neurogenesis, and decrease in brain growth factors (1). Some brain regions are vulnerable to early stress situations because they possess high levels of glucocorticoid receptors and postnatal neurogenesis capacity (6).

In patients exposed to child abuse, functional nuclear magnetic resonance (fMRI) has shown hypo-activation of the orbitofrontal cortex and hyper-activation of the amygdala, which is related to outbursts of aggressiveness and low impulse control $(7,8)$. The exposure to chronic stress caused by child abuse has been associated with delays in the myelination of the corpus callosum in up to $17 \%$ of patients, which promotes the independent development of both cerebral hemispheres generating important changes in the individual's behavior, due to the lateralization of the cerebral neurotransmitter systems (6).

The hippocampal region is very susceptible to the effects of child abuse, mainly between 3-5 years and 11-13 years old, due to the neuronal plasticity that this area presents and the great number of glucocorticoid receptors $(9,10)$. Using magnetic resonance imaging (MRI) techniques, it is believed that early exposure to child abuse could reduce hippocampal volume. However, it is not clear which are the clinical repercussions $(6,9)$.

The cerebellum is an area that plays an important role in attention, language, cognition, affect, and due to its high density of glucocorticoid receptors, it is very vulnerable to the effects of early child abuse. Using MRI in children exposed to child abuse, a decrease in cerebellar volume has been documented, which could explain some neurobehavioral changes produced by abuse (6).

MRI, along with its different sequences such as fMRI, and diffusion sequence magnetic resonance imaging (dMRI), plays a key role in identifying structural and functional alterations in the brain. The objective of this review is to summarize and update the available evidence regarding MRI brain changes and their clinical impact on children exposed to child abuse, to provide a better understanding of the effects of child maltreatment on the brain.

\section{MATERIALS AND METHODS}

To answer the question a systematic literature review was carried out using the "Preferred Reporting Items for Systematic Review and Meta-Analysis" (PRISMA) as a guide.

Eligibility criteria: Cross-sectional studies, case-controls, cohorts, meta-analyses, randomized, and non-randomized clinical trials were considered. The studies had to use MRI in patients exposed to child abuse defined as physical, sexual, emotional abuse, or neglect (determined by questionnaires or adverse situations) (1).

The inclusion criteria were: studies published worldwide, in English, Spanish, and French, performed between January 2015 and March 2020, whose main outcomes evaluated were encephalic alterations and their clinical repercussions secondary to child abuse documented by MRI. The exclusion criteria were patients with post-traumatic stress disorder, participants over 45 years of age, and associated psychiatric pathology. The PICO strategy was used.

Information sources: A systematic search was carried out in the following databases: PubMed, LILACS, ScienceDirect, Embase. The articles that were not open access were accessed through the platform of "Universidad El Bosque".

Search strategy: Broad search words were used instead of specific terms to ensure that no articles were missed. The MESH terms used were: "Child Abuse," OR "child abuse sexual," AND "magnetic resonance imaging," AND "brain". Study selection: All the abstracts of the articles found through the search strategy were reviewed; the full text was 
read in the papers that were considered relevant. The search, selection, and evaluation of the quality of the studies were carried out by two authors: Andrés Herrera (AH) and Nury Rincón (NR), in cases of discrepancies, these were resolved by a third author: Lorena Fernández (LF). Only the articles that met the inclusion and exclusion criteria were included.

Data extraction: The researchers carried out the collection of information based on a data extraction table that included year of publication, type of study, participant information (number of participants, age, gender and country of origin).

Quality assessment: All the articles included were evaluated using the NIH quality assessment tool (www.nhlbi.nih.gov/health-topics/study-quality-assessmenttools). Only studies with results of high or acceptable quality were included.

\section{RESULTS}

Search Results: The studies grouped in the table met all the inclusion and exclusion criteria, also were of high or acceptable quality in the NIH quality assessment tool. Although the search initially yielded nine studies; two of them were excluded because they presented psychiatric illness in the sample, for that reason we obtained a total of seven studies to evaluate (Figure 1).

Summary of studies: 7 studies with a total of 760 participants were included with a mean age ranging between 6-35 years. Their findings showed that child abuse not only has physical repercussions at the moment of the act itself; but also produces long-term consequences at a cerebral level, negatively impacting their anatomy and functionality; in each study MRI, fMRI or dMRI was performed; also different scales and questionnaires were carried out, which contributed to the evaluation and classification of the degree of abuse in the participants (trauma history questionnaire, MacArthur behavior questionnaire, and the PANAS scale).

The Stroop test to evaluate neuropsychological disorders caused by child abuse was employed in two studies. In $42 \%$ of the articles, alterations were evidenced at the level of the amygdala and hippocampus, defined as volume reduction or decreased connectivity. On the other hand, $28 \%$ of the articles included mentioned alterations at the level of the frontal cortex. The following table provides a detailed breakdown of each of the relevant findings (Table 1).

Figure 1: PRISMA diagram. MRI: Magnetic resonance imaging

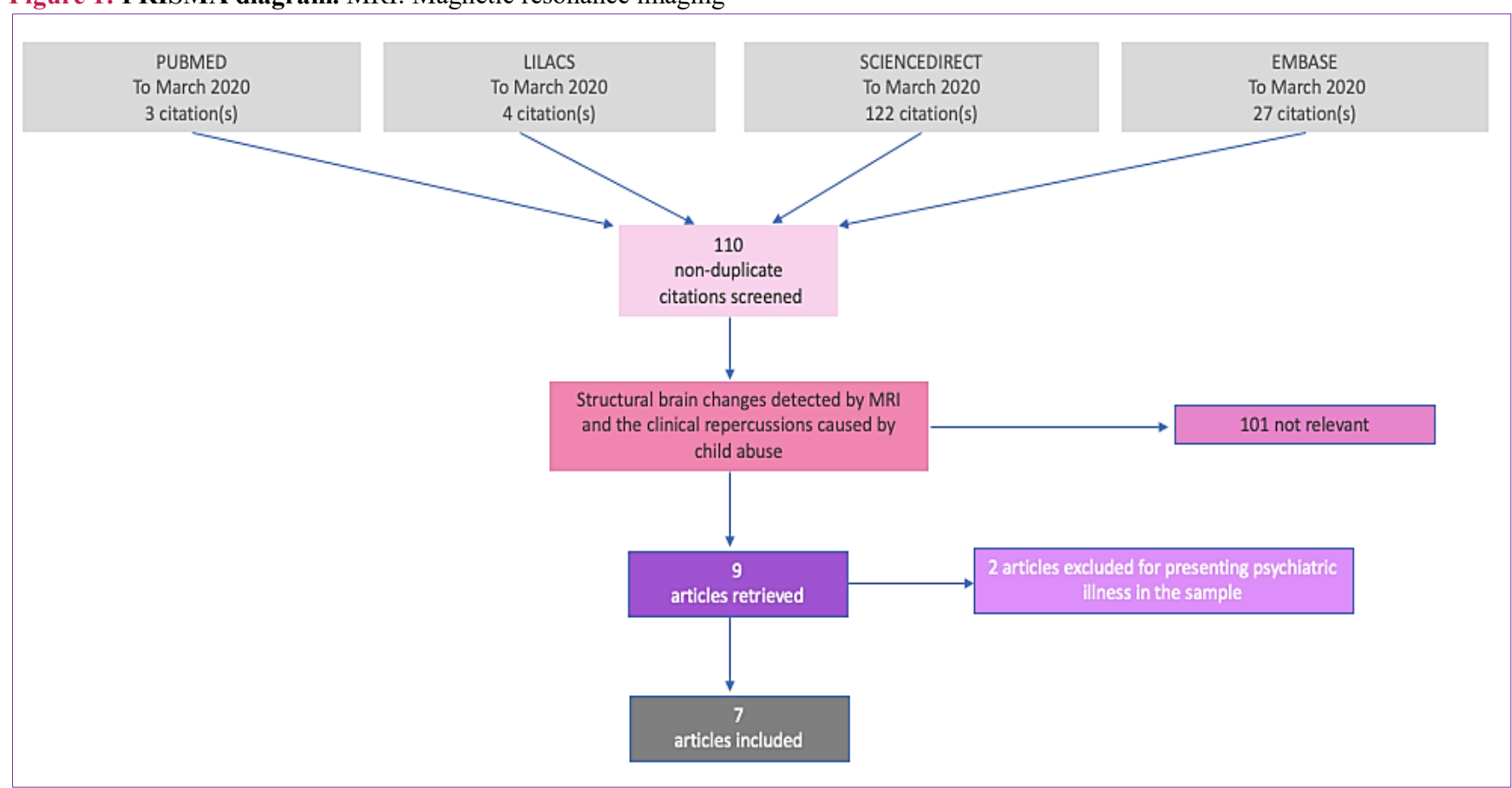

Source: Elaborated by the authors 
Table 1. Summary of study findings.

\begin{tabular}{|c|c|c|c|c|}
\hline Study & Study design & Intervention & Results & Quality \\
\hline $\begin{array}{l}\text { Blair et al. } \\
\text { (11) }\end{array}$ & $\begin{array}{l}\text { Duration: } 2016-2018 \\
\text { Participants: } 116 \text { adolescents between } \\
10 \text { and } 18 \text { years old, } 15 \text { of them without } \\
\text { previous child abuse and } 101 \text { exposed } \\
\text { to any sub-type of child abuse at some } \\
\text { point in their lives. }\end{array}$ & $\begin{array}{l}\text { The participants were given the } \\
\text { "childhood trauma questionnaire" and } \\
\text { subsequently underwent fMRI at the } \\
\text { same time as the "Stroop test" (which } \\
\text { is divided into congruent tasks, } \\
\text { incongruent tasks, and neutral tasks) }\end{array}$ & $\begin{array}{l}\text { The amount of abuse was negatively } \\
\text { correlated with responses to the } \\
\text { incongruous task at the level of the } \\
\text { mid-region of the cingulate cortex ( } \mathrm{r} \text { of } \\
\text { pearson }=-0.33) \text { ( } \mathrm{P}=0.001) \text {, right } \\
\text { postcentral gyrus and lower parietal } \\
\text { lobe }(\mathrm{r} \text { de pearson }=-0.41)(\mathrm{P}=0.001) \text {, } \\
\text { pre-central and left postcentral gyrus }(\mathrm{r} \\
\text { de pearson }=-0.40) \text { ( } \mathrm{P}=0.001) \text {, the } \\
\text { medial region of the frontal cortex ( } \mathrm{r} \text { de } \\
\text { pearson }=-0.40)(\mathrm{P}=0.001) \text {. } \\
\text { These results suggest that child abuse } \\
\text { generates atypical neuronal responses } \\
\text { and alters brain areas involved in } \\
\text { behavior, which is manifested as } \\
\text { increased or decreased brain response } \\
\text { to the Stroop test. }\end{array}$ & $9 / 12$ \\
\hline $\begin{array}{l}\text { Mackiewicz } \\
\text { et al. (12) }\end{array}$ & $\begin{array}{l}\text { Participants: } 15 \text { young adult women. } \\
\text { Age range: } 23-30 \text { years, with a history } \\
\text { of physical or sexual abuse in } \\
\text { childhood before age } 13 \text {. }\end{array}$ & $\begin{array}{l}\text { PHASE 1: Participants underwent the } \\
\text { "trauma history questionnaire" and an } \\
\text { intelligence quotient (IQ) } \\
\text { measurement. } \\
\text { PHASE 2: Afterwards, an MRI and } \\
\text { fMRI were performed during the } \\
\text { "Stroop test." }\end{array}$ & $\begin{array}{l}\text { It was evidenced that earlier age of } \\
\text { exposure to child abuse affects } \\
\text { neuronal systems' activation, mainly at } \\
\text { the level of the anterior region of the } \\
\text { cingulate gyrus and the medial and } \\
\text { lateral area of the prefrontal cortex, } \\
\text { leading to cognitive control issues in } \\
\text { adulthood. }\end{array}$ & $9 / 12$ \\
\hline $\begin{array}{l}\text { McLaughli } \\
\mathrm{n} \text { et al. (13) }\end{array}$ & $\begin{array}{l}\text { Duration: } 2014-2015 \\
\text { Participants: } 94 \text { young people between } \\
6 \text { to } 18 \text { years old exposed to physical } \\
\text { and sexual abuse. } \\
\text { Of the } 94 \text { patients recruited, } 4 \text { were } \\
\text { excluded because they failed to } \\
\text { complete the tests. } \\
\text { Therefore, only } 90 \text { patients were } \\
\text { included in the study. ( } 35 \text { exposed to } \\
\text { abuse and } 55 \text { controls) }\end{array}$ & $\begin{array}{l}\text { The participants underwent MRI and } \\
\text { then the "childhood trauma } \\
\text { questionnaire" was applied to } \\
\text { document the extent of the abuse. } \\
\text { Afterward, the patients presented a fear } \\
\text { conditioning test receiving positive, } \\
\text { negative, and unconditioned stimuli, } \\
\text { which were performed simultaneously } \\
\text { with a skin conductance response test, } \\
\text { to evaluate the activation of the } \\
\text { sympathetic nervous system during the } \\
\text { stimuli. } \\
\text { Participants reported when they were } \\
\text { afraid, when they liked it or if the } \\
\text { stimuli were unpleasant using the } \\
\text { "Likert" scale, which varies from } 0 \\
\text { (none) to } 10 \text { (extreme). }\end{array}$ & $\begin{array}{l}\text { The abuse was associated with a } \\
\text { reduction in total brain volume, } \\
\text { amygdala, and hippocampus; } \\
\text { furthermore, it was concluded that } \\
\text { children exposed to child abuse fail to } \\
\text { discriminate which situations are safe } \\
\text { and which situations represent a threat. } \\
\text { A generalized failure of associative } \\
\text { learning was detected, which makes it } \\
\text { difficult for them to predict when an } \\
\text { unconditioned stimulus will occur. } \\
\text { This interpretation is consistent with } \\
\text { extensive evidence documenting } \\
\text { reduced IQ in children who have been } \\
\text { abused. }\end{array}$ & $10 / 12$ \\
\hline $\begin{array}{l}\text { Cisler et al. } \\
\text { (14) }\end{array}$ & $\begin{array}{l}\text { Duration: } 2011-2016 \\
\text { Participants: } 88 \text { girls between 11-17 } \\
\text { years old ( } 59 \text { girls were exposed to } \\
\text { direct physical or sexual assault and } 29 \\
\text { of them were healthy controls) }\end{array}$ & $\begin{array}{l}\text { fMRI was used to calculate the stimuli' } \\
\text { functional connectivity during the } \\
\text { application of a facial emotion } \\
\text { processing test. Data were then pooled, } \\
\text { and the overall efficiency for stimulus } \\
\text { connectivity was computed using a } \\
\text { brain portion of } 883 \text { regions of interest. }\end{array}$ & $\begin{array}{l}\text { A more modularized network } \\
\text { organization was found to be related to } \\
\text { hyperactivation of the amygdala and } \\
\text { weakened connectivity between the } \\
\text { amygdala and the right }(\mathrm{p}=0.003) \text { and } \\
\text { left }(\mathrm{p}=0.038) \text { medial prefrontal } \\
\text { cortex, which is associated with } \\
\text { increased impulsivity. }\end{array}$ & $11 / 12$ \\
\hline $\begin{array}{l}\text { Calem et al. } \\
\text { (15) }\end{array}$ & $\begin{array}{l}\text { Searching the English literature using } \\
\text { MEDLINE search terms, } 15 \text { articles } \\
\text { were found that evaluated the volume } \\
\text { of the amygdala and hippocampus in } \\
\text { children aged } 12 \text { to } 18 \text { years. } \\
\text { Three of the articles focused on sexual } \\
\text { abuse, six on multiple forms of abuse, } \\
\text { three on stressful events in early life, } \\
\text { two on neglect, and one on poverty. }\end{array}$ & $\begin{array}{l}\text { Measurement of tonsillar and } \\
\text { hippocampal volume in boys and girls } \\
\text { exposed and not exposed to child } \\
\text { abuse. The results were evaluated } \\
\text { through a random-effects analysis. }\end{array}$ & $\begin{array}{l}\text { Patients exposed to child abuse have } \\
\text { smaller hippocampal volumes } \\
\text { compared to unexposed ones, } g \text { of } \\
\text { hedge }-0.15(\mathrm{p}=0.01) \text {. } \\
\text { When contrasting the hippocampal } \\
\text { volume by gender in patients exposed } \\
\text { to previous child abuse, a clinically } \\
\text { relevant difference was not evidenced } \\
(\mathrm{P}=0.012)\end{array}$ & $7 / 8$ \\
\hline
\end{tabular}




\begin{tabular}{|c|c|c|c|c|}
\hline Study & Study design & Intervention & Results & Quality \\
\hline $\begin{array}{c}\text { Bick et al. } \\
\text { (16) }\end{array}$ & $\begin{array}{l}\text { Participants: } 69 \text { children between the } \\
\text { ages of } 8-10 \text { years were extracted from } \\
\text { the study "Bucharest early intervention } \\
\text { project", } 23 \text { of them were in foster care } \\
\text { exposed to neglect, } 26 \text { were raised in } \\
\text { institutions exposed to severe neglect, } \\
\text { and } 20 \text { had never been in institutional } \\
\text { care. }\end{array}$ & $\begin{array}{l}\text { All of the children had a dMRI at ages } \\
8 \text { and } 10 . \text { Depressive and anxiety } \\
\text { symptoms were assessed using the } \\
\text { "MacArthur" behavioral questionnaire } \\
\text { at the moment of the dMRI and at } 12 \\
\text { and } 14 \text { years old. }\end{array}$ & $\begin{array}{l}\text { An increased mean diffusivity } \\
(\mathrm{P}=0.02) \text { and decreased fractional } \\
\text { anisotropy ( } \mathrm{P}=0.01) \text { at the corpus } \\
\text { callosum were evidenced in children } \\
\text { raised in foster care and institutions. } \\
\text { Also, these children presented an } \\
\text { increased mean diffusivity ( } \mathrm{P}=0.03) \\
\text { and a decreased fractional anisotropy } \\
(\mathrm{P}=0.025) \text { at the left internal capsule. } \\
\text { These findings suggest an alteration in } \\
\text { the myelination of these areas, } \\
\text { associated with increased anxiety and } \\
\text { depression. }\end{array}$ & $12 / 14$ \\
\hline $\begin{array}{c}\text { Everaerd et } \\
\text { al. (17) }\end{array}$ & $\begin{array}{l}\text { Participants: } 382 \text { subjects between the } \\
\text { ages of } 18-35 \text {, who were divided into } \\
\text { three groups. } \\
\text { *Group exposed to physical, } \\
\text { emotional, or sexual abuse: } 127 \\
\text { patients } \\
\text { *Group exposed to deprivation: } 126 \\
\text { patients } \\
\text { *Healthy control group: } 129 \text { patients }\end{array}$ & $\begin{array}{l}\text { The participants underwent MRI with } \\
\text { T1 sequence and then divided into } \\
\text { three groups (exposed to physical } \\
\text { abuse, exposed to deprivation, healthy } \\
\text { control), to evaluate their emotional } \\
\text { state based on age, sex, and the result } \\
\text { of the PANAS scale. }\end{array}$ & $\begin{array}{l}\text { Patients with a history of deprivation } \\
\text { presented decreased volume of gray } \\
\text { matter at the fusiform gyrus and medial } \\
\text { occipital gyrus ( } \mathrm{P}=0.05 \text { ). These areas } \\
\text { are related to the emotional perception } \\
\text { of the scenarios and faces. } \\
\text { In women with a history of deprivation } \\
\text { and child abuse, a decreased volume of } \\
\text { the gray matter at the lower right visual } \\
\text { region and the posterior precuneal } \\
\text { region was evidenced ( } \mathrm{P}=0.05 \text { ); these } \\
\text { areas are related to the processing of } \\
\text { emotions. In men with a history of } \\
\text { deprivation, a decreased gray matter } \\
\text { volume at the post-central gyrus was } \\
\text { seen ( } \mathrm{P}=0.001 \text { ). } \\
\text { These differences in results by gender } \\
\text { could justify the different psychiatric } \\
\text { disorders in men and women, which } \\
\text { would explain why depression is more } \\
\text { frequent in women and impulse control } \\
\text { disorders are more frequent in men. }\end{array}$ & $9 / 12$ \\
\hline
\end{tabular}

Source: Elaborated by the authors; fMRI: functional nuclear magnetic resonance; dMRI: diffusion sequence magnetic resonance imaging; MRI: magnetic resonance imaging

\section{DISCUSSION}

The results of this review indicate that patients exposed to different sub-types of child abuse have in common diverse manifestations, both clinical, and anatomical. However, it should be pointed out that each sub-type of abuse generates characteristic structural and functional changes in the brain; therefore, the clinical repercussion of the patient will largely depend on the sub-type of child abuse to which he or she has been exposed (18). Patients who suffered physical or sexual abuse in childhood present predominantly impulsivity along with difficulty in discriminating threatening scenarios. On the other hand, patients exposed to negligence or emotional abuse present more frequently cognitive alterations such as disruption of learning and memory (11).
All subtypes of child abuse have been associated with alterations of neuronal activation at the level of the cingulate gyrus, pre-central gyrus, post-central gyrus, lower parietal lobe $(11,19)$ along with decreased volume in the ventromedial region of the frontal cortex. All these findings are related to the decrease in cognitive control presented by these patients $(20,21)$.

Physical and sexual abuse in childhood typically results in hyperactivation and decreased volume of the amygdala. Hippocampus thinning and reduced connectivity at the medial prefrontal cortex are associated with reduced IQ, difficulty discriminating threatening scenarios, impulsivity, and aggression disorders $(13,14)$. Recent research has linked physical and sexual abuse in childhood to the development of borderline personality disorders in adulthood (22). 
Both, negligence and emotional abuse in childhood produce similar structural and functional changes (21); such as alteration in the myelination of the corpus callosum; which has been associated with increased anxiety, depression, and cognitive alterations of the working memory, attention, and processing of emotions (16).

Deprivation in childhood has been shown to structurally affect the brain by decreasing gray matter at the fusiform gyrus and medial occipital gyrus, associated with altered emotional perception of scenarios and faces.

Patients exposed to deprivation presented different anatomical changes between genders. In women, a decreased gray matter has been seen in the lower right visual region and the anterior precuneal region, leading to alterations in the processing of emotions, predisposing them to depression. A decreased gray matter in the post-central gyrus has been seen in men, predisposing them to increased impulsivity (17). These differences in results by gender could justify the different psychiatric disorders in men and women, which would explain why depression is more frequent in women and impulse control disorders are more frequent in men. $(17,23$ 24).

One of the limitations of this study is that the assessment of child abuse repercussion was done through test scores instead of evaluating daily living behavior, which can induce bias.

The importance of describing these findings lies in the fact that early intervention by removing these children from the abuse focus; has demonstrated the reversibility of structural and functional changes in the brain (25).

\section{CONCLUSIONS}

In this review, it is possible to conclude that long-term child maltreatment leads to structural and functional changes in the brain, which may be reversible if early intervention is made by removing these children from the abuse focus, a concept that is in line with the literature so far. It is possible to conclude that the structural changes in the brain vary depending on the sub-type of child abuse; nevertheless, it remains in controversy which changes correspond to each sub-type of child abuse, due to the multifactorial nature of brain plasticity and the lack of publications that break down anatomical and functional alterations by sub-types of abuse. For that reason, more literature is needed to support the results displayed and to deliver an accurate concept. Concerning the limitations of the study, it is not possible to conclude if there are clinically significant structural changes between genders due to the low number of publications regarding the subject. To date, this subject continues to be an active research topic, for which literature and research networks must be expanded.
Conflicts of Interest: The authors do not declare any conflicts of interest.

\section{REFERENCES}

1. Brian C. Kavanaugh, Jennifer A. Dupont-Frechette, Beth A. Jerskey \& Karen A. Holler Neurocognitive Deficits in Children and Adolescents Following Maltreatment: Neurodevelopmental Consequences and Neuropsychological Implications of Traumatic Stress, Applied Neuropsychology: Child, 2016; 64 (1) 6 648. doi:10.1080/21622965.2015.1079712

2. McLaughlin KA, Sheridan MA, Lambert HK, KA. M, MA. S, HK. L. Childhood adversity and neural development: deprivation and threat as distinct dimensions of early experience. Neurosci Biobehav Rev. 2014; 47 (1) 578-591. doi: 10.1016/j.neubiorev.2014.10.012

3. ICBF: Instituto Nacional del bienestar familiar. Bogotá D.C:ICBF;2013.https://www.icbf.gov.co/sites/default/files/pu blicacion-37.pdf

4. Dongdong Li, Chi Meng Chu, Grace S. Chng, Ming Hwa Ting.Child Abuse and Neglect. Singapore: Academic Press; 2019. doi: 10.1016/B978-0-12-815344-4.00019-2

5. Deambrosio, M., Gutiérrez de Vázquez, M., Arán-Filippetti, V., \& Román, F. Efectos del Maltrato en la Neurocognición. Un Estudio en Niños Maltratados Institucionalizados y no Institucionalizados. Revista Latinoamericana de Ciencias Sociales, Niñez y Juventud, 2016; 16(1), 239-253. doi:10.11600/1692715x.16114

6. Amaro Hurtado F. Maltrato infantil y neurociencias.

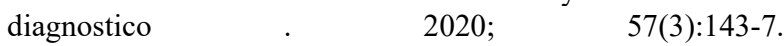
doi: $10.33734 /$ diagnostico.v57i3.187

7. van Harmelen AL, van Tol MJ, Demenescu LR, van der Wee NJA, Veltman DJ, Aleman A, et al. . Enhanced amygdala reactivity to emotional faces in adults reporting childhood emotional maltreatment. Soc Cogn Affect Neurosci. 2013. 8(4):362-369. doi:10.1093/scan/nss007

8. van Harmelen AL, van Tol MJ, Dalgleish T, van der Wee NJ, Veltman DJ, Aleman A, et al. . Hypoactive medial prefrontal cortex functioning in adults reporting childhood emotional maltreatment. Soc Cogn Affect Neurosci. 2014. 9(12): 20262033. doi: $10.1093 / \mathrm{scan} / \mathrm{nsu} 008$

9. Ward AM, Schultz AP, Huijbers W, Ra Van Dijk K, Hedden T, Sperling RA. The parahippocampal gyrus links the defaultmode cortical network with the medial temporal lobe memory system. Hum Brain Mapp. 2014.35(3): 1061-1073. doi : 10.1002/hbm.22234

10. Paquola C, Bennett MR, Lagopoulos J. Understanding heterogeneity in grey matter research of adults with childhood maltreatment - a meta-analysis and review. Neurosci Biobehav Rev. 2016. 69(1):299-312. doi:10.1016/j.neubiorev.2016.08.011

11. Blair KS, Aloi J, Crum K, et al. Association of Different Types of Childhood Maltreatment With Emotional Responding and Response Control Among Youths. JAMA Netw Open. 2019;2(5):1-15. doi:10.1001/jamanetworkopen.2019.4604

12. Mackiewicz S, DePrince AP, Banich M, Association Between 
Initial Age of Exposure to Childhood Abuse and Cognitive Control: Preliminary Evidence. Journal of traumatic stress. 2018 31(3): 437-447.doi: 10.1002/jts.22290.

13. McLaughlin K., Sheridan M., Gold A., Duys A., Lambert H. , Matthew Peverill M., et al. Maltreatment Exposure, Brain Structure, and Fear Conditioning in Children and Adolescents. Neuropsychopharmacology. 2016; 41(8): 1956-1964. doi: $\underline{10.1038 / \mathrm{npp} .2015 .365}$

14. Cisler JM, Privratsky A, Smitherman S, Herringa RJ, Kilts CD. Large-scale brain organization during facial emotion processing as a function of early life trauma among adolescent girls. Neuroimage:clinical 2017. 17 (1):778-785. doi: 10.1016/j.nicl.2017.12.001.

15. Calem M, Bromis K, McGuire P, Morgan C, Kempton MJ. A meta-analysis of associations between childhood adversity and hippocampus and amygdala volume in non-clinical and general population samples.Neuroimage:clinical. 2017; 14 (1):471-479. doi: 10.1016/j.nicl.2017.02.016.

16. Bick J, Fox N, Zeanah C, Nelson CA Early deprivation, atypical brain development, and internalizing symptoms in late childhood.Neuroscience. 2017;342 (1):140-153. doi: 10.1016/

17. Everaerd D, Klumpers F, Zwiers M, Guadalupe T, Franke B, Et al. Childhood abuse and deprivation are associated with distinct sex-dependent differences in brain morphology. Neuropsychopharmacology.2016;41(7):1716-1723. doi: $\underline{10.1038 / \mathrm{npp} .2015 .344 \text {. dsfdf }}$

18. Carr CP, Martins CMS, Stingel AM, Lemgruber VB, Juruena MF. The role of early life stress in adult psychiatric disorders: a systematic review according to childhood trauma sub-types. J Nerv Ment Dis. 2013;201(12):1007-1020. doi:10.1097/NMD.0000000000000049
19. Stevens JS, Ely TD, Sawamura T, et al. Childhood maltreatment predicts reduced inhibition-related activity in the rostral anterior cingulate in ptsd, but not trauma-exposed controls. Depress Anxiety. 2016;33(7):614-622. doi:10.1002/da.22506

20. Gold AL, Sheridan MA, Peverill M, et al. Childhood abuse and reduced cortical thickness in brain regions involved in emotional processing. J Child Psychol Psychiatry. 2016;57(10):1154-1164. doi:10.1111/jcpp.12630

21. Cassiers LLM, Sabbe BGC, Schmaal L, Veltman DJ, Penninx BWJH, Van Den Eede F. Structural and Functional Brain Abnormalities Associated With Exposure to Different Childhood Trauma Sub-types: A Systematic Review of Neuroimaging Findings. Front Psychiatry. 2018;9(1):329-346. doi:10.3389/fpsyt.2018.00329

22. Westen, D., Ludolph, P., Misle, B., Ruffins, S., \& Block, J. Physical and sexual abuse in adolescent girls with borderline personality disorder. American Journal of Orthopsychiatry, 1990; 60(1), 55-66. doi.org/10.1037/h0079175

23. Cyranowski JM, Frank E, Young E, Shear MK. Adolescent onset of the gender difference in lifetime rates of major depression: a theoretical model. Arch Gen Psychiatry. 2000;57(1):21-7. doi: 10.1001/archpsyc.57.1.21.

24. Kessler RC, McGonagle KA, Swartz M, Blazer DG, Nelson CB . Sex and depression in the National Comorbidity Survey. I: lifetime prevalence, chronicity and recurrence. J Affect Disord. 1993. 29(3) 85- 96. doi: 10.1016/01650327(93)90026g

25. Bick, J., Nelson, C. Early Adverse Experiences and the Developing Brain. Neuropsychopharmacol . 2016;41(1); 177 196 doi.org/10.1038/npp.2015.252 